\title{
A Study on 126 Cases of Thyroid Tumor
}

\author{
Haruka Tanaka ${ }^{1)}$, Yasunori Aoyagi ${ }^{1)}$, Hiromitsu Akizuki ${ }^{1)}$, \\ Ryota Mashiko ${ }^{2)}$ and Yasushi Shibata ${ }^{2)}$
}

The 126 patients were surgically treated for thyroid tumors in our hospital between April, 2002 and July, 2013. Female patients were more frequent than males. In $66.7 \%$ of the cases the tumors were benign (adenomatous goiter was the most frequent) and malignant tumors accounted for 33.3\% (papillary carcinoma was the most frequent). There were patients who had no subjective symptoms, when their thyroid tumors were discovered incidentally during a routine medical examination. In fine needle aspiration cytological diagnosis, the sensitivity value was $96.0 \%$ and specificity value was $84.2 \%$, and accuracy value was 87.1\%. In TNM classification, $71.4 \%$ of the cases comprised T1 and T2. N1 accounted for $52.4 \%$ and N0 for 47.6\%. Among those patients with malignant tumors, 2 died. The remaining 40 patients are alive at present. Recurrence was found in 6 cases.

Keywords : thyroid tumor, subjective symptoms, medical examination, fine needle aspiraion cytological diagnosis

\section{References}

1) Sakurai K, Iwata $S$, Nishimura $T$, et al. : A clinical study of 65 patients with thyroid tumors. Pract Otol (Kyoto) 76: 11671173, 1983.

2) 八十島孝博, 水島康博, 秋山守文, 他: 甲状腺腫瘍手術 123 例の臨床病理学的検討. 臨と研 73: 2301-2304, 1996.

3) 久保井敬之, 坂倉 淳, 中井健, 他: 主訴からみた甲状 腺腫の診断過程一甲状腺手術症例からの検討一. 日気管食 道会報 46: 235-241, 1995.

4）太田伸男, 原田次郎, 大木 誠, 他：当科における甲状腺 腫瘍症例一臨床統計と術前診断の有用性一. 耳鼻 - 頭頸外 科 68: 250-253, 1996.

5) 高橋和彦, 大久保英樹, 瀬成田雅光, 他：当科における甲 状腺腫瘍症例の臨床的検討. 耳鼻展望 42: 108-112, 1999.

6) 中村和隆, 青柳安典, 秋月浩光 : 水戸協同病院耳鼻咽喉科 における甲状腺手術症例の検討. 茨城農村医会誌 21：75$78,2008$.

7）小池明彦：甲状腺癌の病態生理と臨床. 医事新報 3512: 13-
$17,1991$.

8）末広史恵, 井上修志, 坪崎英治 : 総合検診における結節性 甲状腺腫の発見率とその検討. 臨と研 68: 1073-1078, 1991.

9) Hundahl SA, Cady B, Cunningham MP, et al. : Initial results from a prospective cohort study of 5583 cases of thyroid carcinoma treated in the united states during 1996. U.S. and German Thyroid Cancer Study Group. An American College of Surgeons Commission on Cancer Patient Care Evaluation study. Cancer 89: 202-217, 2000.

10）鳥屋城男：甲状腺腫瘤の穿刺吸引細胞診. JOHNS 3: 14951499, 1987.

11）江崎治夫, 松山敏哉：甲状腺の穿刺吸引細胞診. 臨と研 62: 2080-2088, 1985.

12）青柳安典, 秋月浩光, 藤井慶太郎, 他：反回しない反回神 経の一症例. 茨城農村医会誌 23: 71-75, 2010.

13) Nishikawa A, Kitamura H, Oyagi S, et al. : Non-recurrent laryngeal nerve-a case report-. Pract Otol (Kyoto) Suppl 23: 165-168, 1988.
1) Department of Otolaryngology, Mito Kyodo General Hospital

2) Department of Neurosurgery, Mito Kyodo General Hospital
Corresponding Author Address : Haruka Tanaka mito@mitokyodo-hp.jp 
Pathological diagnoses

\begin{tabular}{lc}
\hline \hline Benign (84 cases), male:female $=16: 68$ \\
\hline Adenomatous goiter & 60 cases \\
Follicular adenoma & 19 \\
Cyst & 3 \\
Lymphoepithelioma & 1 \\
Amyloid deposition & 1 \\
\hline Malignant (42 cases), male:female $=12: 30$ \\
\hline Papillary carcinoma & 34 \\
Follicular carcinoma & 7 \\
Medullary carcinoma & 1
\end{tabular}

